\title{
Learning Analytics som udgangspunkt for refleksion over didaktisk design \\ - i blended learning
}

\section{Anne-Mette Nortvig}

Adjunkt og lektor, ph.d.

Adjunkt ved Aalborg Universitet, Institut for Læring og Filosofi og lektor ved University College Sjælland, Center for Skole og Læring

Anne-Mette Nortvig er ansat som adjunkt på Aalborg Universitet i København ved Institut for Læring og Filosofi og samtidig som lektor på University College Sjælland ved Center for Skole og Læring i Roskilde. Begge steder forsker hun $i$ didaktisk design, læring og it. Anne-Mette Nortvig er ph.d. i It og Læring og har publiceret en række artikler og bidrag til bøger inden for dette felt. 


\section{Abstract}

Denne artikel vil tage udgangspunkt i learning analytics, som et nyt felt i forskningen inden for bl.a. it-didaktisk design, og artiklen vil argumentere for, at learning analytics kan og bør bidrage til designrefleksioner.

Med empiri fra et blended learning-baseret mastermodul ved Aalborg Universitet vil artiklen præsentere, analysere og diskutere to cases, hvori learning analytics spiller en central rolle. I den ene case undersøges det, hvordan studerende bruger og interagerer med video podcasts som forberedelse til face-to-face undervisning, når podcasten henviser til andre læringsressourcer hhv. fungerer som stand-alone ressource. I den anden case undersøges, - ligeledes gennem learning analytics - hvilken indflydelse øjenkontakt har for de studerendes interaktion med video podcasts og for deres udbytte af dens indhold.

Artiklen peger på, at et mix af kvantitative og kvalitative data kan bidrage til at udvide forståelse af studerendes læring og interaktioner med læringsressourcer, og den argumenterer for, at der med inddragelse af learning analytics kan skabes anledning til nye refleksioner over et didaktisk design.

\section{Abstract in English}

This article takes its point of departure from learning analytics, which is a new field within research in ICT and learning design. The paper argues that learning analytics can and should contribute to design reflections.

With empirical data from a master's module based on blended learning at Aalborg University, the article presents, analyses and discusses two cases in which learning analytics play an important role. The first case investigates how students use and interact with video podcasts in preparation for face-toface lessons when the podcasts relate to other learning resources or are used as a stand-alone resource. The second case employs a learning analytics lens to explore how eye contact influences students' interaction with video podcasts and their learning outcome.

The article emphasises that a mix of quantitative and qualitative data can contribute to a broader understanding of students' learning and interaction with learning resources, arguing that the use of learning analytics can contribute to new reflections on a particular learning design.

\section{Introduktion}

I undervisning på skoler og andre uddannelsesinstitutioner finder undervisere det normalt nødvendigt at danne sig et indtryk af, hvordan deres elever eller studerende tager imod undervisningen, og om de forstår det, der foregår og lærer noget af det. Dette sker fx ved, at underviseren forsøger at registrere og 
evaluere de studerendes engagement, deres interaktioner med hinanden, med læringsressourcerne og med underviseren. Tilstedeværelse i det fysiske lokale sammen med studerende eller elever kan således bidrage til underviserens billede af, hvordan det går, og om noget skal ændres i den måde, man underviser på, i de ressourcer man inddrager eller i de aktiviteter, man sætter i gang. Ikke mindst i de senere år, hvor fokus i undervisning ofte lægges på den lærende i højere grad end på formidling af indhold på samme måde til alle, så er refleksioner over måder at følge de studerendes arbejde og interaktioner med stof, medstuderende og underviser blevet centralt.

Når undervisningen foregår i online eller blendede formater, og aktiviteterne dermed af og til afvikles asynkront online, kan den løbende evaluering af studerendes reaktioner på undervisningsdesignet imidlertid synes vanskeligere at få adgang til umiddelbart. Derfor må man her som underviser ty til andre måder at evaluere og løbende justere sit didaktiske design på, og man må finde andre adgange til tegn på læring og udtryk for interaktion hos de studerende, når de enten helt eller i perioder arbejder online. Samtidig skaber sådanne digitale interaktioner dog også mængder af data, som kan indsamles, analyseres og tolkes bl.a. med henblik på at forbedre det didaktiske design (Persico \& Pozzi, 2015), så flere studerende får bedre udbytte af undervisningen, engageres mere - eller hvilket overordnet mål man nu har for sin undervisning. Nedenfor skal vi se nærmere på, hvordan man i forskningen i de seneste år har udviklet og diskuteret denne tilgang til brug af data med henblik på læring og design, en tilgang, der nu kaldes learning analytics.

\section{Learning analytics}

Selvom man blandt forskere ikke er blevet enige om nogen entydig forståelse af begrebet, ses det ofte siden den første internationale konference om learning analytics i 2011 defineret som "the measurement, collection, analysis and reporting of data about learners and their contexts, for purposes of understanding and optimizing learning and the environments in which it occurs" (Vatrapu, Teplovs, Fujita, Bull, \& Long, 2011, p. 93). Som det ses, handler learning analytics både om at skabe og gøre brug af data med henblik på didaktisk design, med alt hvad det indbefatter. Begrebet minder altså om evaluering, men til forskel herfra lægges der i learning analytics-feltet ofte vægt på indsamling og analyser af de " [...]traces that learners leave behind and using those traces to improve learning" (Duval \& Verbert, 2012). Learning analytics arbejder derfor ofte med big data i form af fx click streams eller optællinger af online forum bidrag, men forskning i dette felt peger også på, at mangefacetterede big data fra studerendes online aktiviteter kan give undervisere adgang til viden om deres studerendes læringsveje, og på baggrund af denne viden har de således mulighed for mere målrettet og effektivt at forbedre deres undervisning (Dyckhoff, Zielke, Bültmann, Chatti, \& Schroeder, 2012; Persico \& Pozzi, 2015). Endvidere kan learning analytics 
bruges til bl.a. forudsigelser af hvilke studerende, der sakker bagud og måske er truet af frafald (Merceron, Blikstein, \& Siemens, 2016; Yasmin, 2013). Når mange studerende nemlig skaber data løbende, vil de studerende, der senere falder fra, sætte særlige mønstre gennem deres digitale fodspor, og disse mønstre kan på senere årgange bruges til at spotte frafaldstruede, så der kan tages hånd om dem, inden de faktisk falder fra. Med big data kan undervisere og institutioner således få adgang til viden om de studerendes handlinger og valg, endnu før de træffes (Tang, Xie, \& Wong, 2015). De mange etiske spørgsmål, der kan rejses med baggrund heri, skal jeg dog ikke komme ind på i denne artikel.

Learning analytics er et forholdsvist nyt forskningsfelt generelt, påpeger flere (Merceron et al., 2016; Schwendimann et al., 2016), og forskning i udnyttelse og forståelse af de pædagogiske potentialer i learning analytics er det specielt (Johnson, Smith, Willis, Levine, \& Haywood, 2011). Således kan også kritik og diskussion af learning analytics ses udtrykt blandt forskere, og især er opmærksomheden her rettet mod behovet for at lade læringsteori og viden fra uddannelsesforskning understøtte anvendelsen af og formålet med learning analytics (Gaševic, Dawson, Rogers, \& Gasevic, 2016). Derudover peges der på nødvendigheden af, at ikke alene forskere men også undervisere og lærere burde indsamle og tolke data, og træffe beslutninger og handle på baggrund af dem (Reyes, 2015) med henblik på læring og undervisning (Clow, 2013; Dyckhoff et al., 2012; Gaševic et al., 2016). De data, der bruges i learning analytics er ofte skabt gennem uddannelsesinstitutioners virtual learning environments (VLE), men der kan argumenteres for, at det for at kunne skabe mere troværdigt visualiserede profiler af de studerende kan være en fordel også at inddrage data fra andre kilder fx data genereret gennem brug af mobile devices eller fra den fysiske verden (Siemens, 2012).

Learning analytics kan bruges på særdeles varieret vis, og data kan skabes i mængder og fra mangfoldige kilder. Nedenfor skal feltet imidlertid indsnævres, så brugen af learning analytics hovedsageligt fokuserer på evaluering af og refleksion over forskellige elementer i didaktisk design. Jeg søger derfor at besvare spørgsmålet, hvordan learning analytics gennem et mix af kvantitative og kvalitative data kan bidrage til at udvide en forståelse af studerendes læring og interaktioner med læringsressourcer, og jeg vil argumentere for, at inddragelse af sådanne data kan - og bør - give anledning til nye refleksioner over et didaktisk design. Empirien er skabt i en masteruddannelse ved Aalborg Universitet, hvor jeg sammen med min kollega, prof. Birgitte Holm Sørensen, har undervist gennem fem år.

\section{Reaktioner på didaktisk design}

Undervisning er jo ikke raketvidenskab; det er meget mere komplekst, skriver Laurillard (2012). Når man derfor er optaget af at designe undervisning og efterfølgende at analysere, hvordan de studerende fx har interageret med 
specifikke læringsressourcer og opgaver, må man til stadighed holde sig klart, at de design, man laver, og de svar, man finder gennem analyser og evalueringer efterfølgende, altid er påvirkede af en mængde kontekstuelle forhold. De studerende reagerer langt fra altid på designet, som man havde forventet, og det kan derfor være en fordel, fx at skelne mellem task og activity (Beetham, 2013), så designet i sig selv og reaktionerne på det holdes adskilte. Task forstås her (ibid.) som opgaven, underviseren har designet, mens activity er udtrykket for den studerendes reaktion på opgaven. Hvis man som underviser fx beder elever om at lytte til et oplæg (som task), kan deres reaktioner (activities) bestå $i$, at de lytter, giver sig til at tegne, skrive noter, dagdrømme, begynder at stille spørgsmål til den osv. Det er disse reaktioner på designet, der har betydning for læring, påpeges det af mange (jf. Beetham, 2013, p. 31), og som derfor (også) er relevante at undersøge med learning analytics.

Nedenfor skal der zoomes ind på den del af et didaktisk design, der hos Laurillard (2012) kaldes "learning through acquisition", og der skal ses på de konsekvenser, en læringsressource har for student-content-interactions (jf. Anderson, 2004) - eller anderledes udtrykt - de studerendes activities som reaktioner på læringsressourcen som et element i en task. Med to cases fra en masteruddannelse ved Aalborg Universitet skal jeg nedenfor først beskrive to udvalgte elementer i det overordnede didaktiske design. Begge elementer blev designet med henblik på i første omgang at præsentere modulets nye studerende for grundlæggende teori i faget og for den opgave, der skulle afleveres $i$ afslutningen af modulets og som pædagogisk var funderet $i$ problem and project based learning (PBL). Overordnet blev begge elementer designet med henblik på styrkelse af kompetencer til analyse og refleksion over didaktisk design blandt de studerende og med henblik på at underviserne under brug af learning analytics kunne evaluere, diskutere, reflektere, lære af og evt. forbedre designet efterfølgende.

\section{Case I: Studerendes interaktioner med video podcast}

Dette design (se også Nortvig \& Sørensen, 2016) blev afviklet med studerende, der skulle introduceres for begrebet didaktik og forskellige didaktiske retninger samt for teori om analyser og design af læremidler. Modulet var overordnet designet som et blended forløb med vægt på online aktiviteter og vejledning samt et enkelt face to face (F2F) seminar udstrakt over to dage. Med et intenst forløb og kort tid til dialog i samme fysiske rum, vurderede vi det nødvendigt at styrke udbyttet af F2F-undervisningen på campus. Vi så en mulighed for at gøre dette ved at flytte nogle af vores normale forelæsninger ud af det fysiske lokale og lægge dem på nettet som video podcasts (jf. Zhang, Zhou, Briggs, \& Nunamaker, 2006), så de studerende kunne se og høre dem i forvejen, inden vi mødtes til seminaret, og vi snarere end at bruge megen tid på monolog kunne bruge den på dialog og samarbejde her. Samtidig ville vi 
forsøge at sørge for, at der blev skabt yderligere sammenhæng mellem den undervisning, der foregik online i forberedelsen og den, der foregik i det fælles fysiske lokale ved i den ene video at indbygge aktiviteter, som skulle påbegyndes afviklet online og afsluttes, når vi mødtes F2F.

Vi optog derfor to video podcasts: den ene var en optagelse af en forelæsning om læringsteori, hvor underviseren talte til kameraet og understøttede forelæsningens pointer og progression via PowerPoint-slides. Forskningen (Dupagne, Millette, \& Grinfeder, 2009; Green et al., 2003; Vajoczki, Watt, Marquis, \& Holshausen, 2010) fremhæver ofte, at studerende ser store læringsmæssige fordele i video podcasts. Særligt påpeges det forhold, at podcasts er nyttige til repetition (Hill \& Nelson, 2011; Kay, 2012), og vores to forelæsninger var netop indholdsområder, de studerende med fordel kunne gense og bruge ved udarbejdelse af deres afsluttende modulopgave. Vi optog med Camtasia (camtasia-studio.da.softonic.com), så den endelige produktion bestod af en picture-in-picture video.

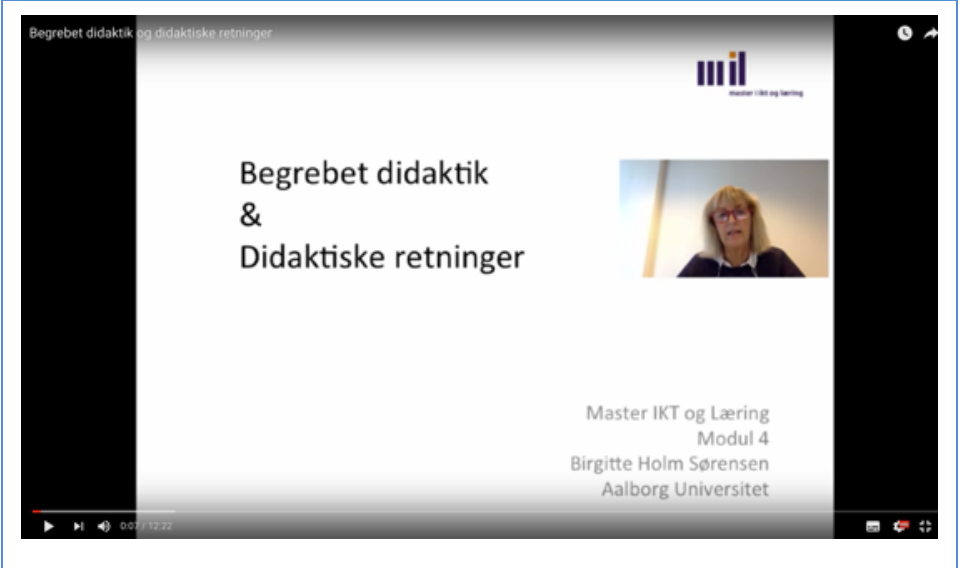

Figur 1: Screendump fra YouTube af den ene video, hvor det ses, at underviseren taler direkte til de studerende i picture-in-picture.

Med denne læringsressource lagde vi vægt på, at de studerende havde muligheden for at se forelæsningen i det tempo, på den tid, det sted og de antal gange, de havde brug for (jf. Heilesen, 2010; Hill \& Nelson, 2011; Jarvis \& Dickie, 2009; Traphagan, Kucsera, \& Kishi, 2010), og at de selv afgjorde, hvordan de derudover ville arbejde med ressourcen (jf. De Boer, Kommers, \& De Brock, 2011).

Den anden video podcast var designet med henblik på også at stilladsere aktiviteter i relation til forelæsningen samt forbinde refleksioner mellem det virtuelle og fysiske rum. Dette gjorde vi ved på videoen at linke til en side, hvor der lå quizzer og spørgsmål, der opfordrede til eftertanke. Spørgsmålene skulle således besvares undervejs, mens de studerende så videoen. Der blev altså i videoen opfordret til, at der blev sat på pause, besvaret spørgsmål osv., 
hvorefter de studerende skulle vende tilbage til video igen. Også denne var optaget i Camtasia i picture-in-picture format.

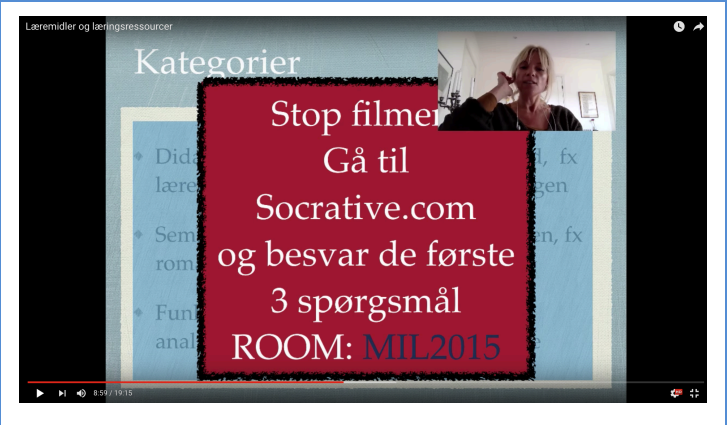

Figur 2: Screendump fra YouTube af den anden video, hvor underviseren taler direkte til de studerende og hvor der opfordres til andre aktiviteter undervejs.

Forskningsinteressen i dette designeksperiment lå i at finde ud af, hvordan de studerende interagerede med videopodcasts, der enten stilladserede aktivitet og refleksion eller ikke gjorde. Med definitionen af learning analytics (Vatrapu et al., 2011) in mente, havde vi her interesse i at måle og analysere de lærendes reaktioner på og interaktioner med det didaktiske design som læringsressource med henblik på både at forstå men også samtidig at forbedre designet, - eller formuleret med reference til Beetham (2013), at analysere de studerendes activities i relation til vores tasks. Da vi ikke havde adgang til observationer af de studerende, mens de så videoerne men derimod lod dem sætte en mængde digitale fodspor, var det disse, der dannede data til vores learning analytics.

\section{Data}

Videopodcastene blev distribueret til de studerende via YouTube, og udover at være let for de studerende at tilgå, generer YouTube også data over blandt andet hvor længe, hvor tit, hvor mange og hvordan brugerne har set den enkelte video. Med teknologi, der her kaldes "relative audience retention" får man således adgang til oversigt over, hvordan gruppen af seere har stoppet, sat på pause, spolet og fastforward'et i videoen, når den sammenlignes med andre videoer på YouTube af samme længde og indhold (Alexandros, Alexandros, \& Georgios, 2013). At undersøge studerendes såkaldte "viewing patterns" er i vækst inden for uddannelsesforskning og bidrager ofte til analyser af studerendes brug af podcasts (Kay, 2012). I vores learning analytics undersøgelser af det didaktiske design bidrog disse YouTube data således til at skabe et billede af, om de studerende så vores videoer til ende, eller om de opgav halvvejs fx, og om det lykkedes os at få de studerende til at skifte mellem det at se video, svare på spørgsmål i quiz og stille reflekterende spørgsmål, som kunne opfølges på seminaret. 
Kurven (figur 4), der dannedes for videoen, der linkede til aktiviteter og opfordrede til refleksionsspørgsmål, viste, - når vi analyserede den og betragtede de studerendes viewing pattern som udtryk for én gruppe, - at de studerende så, pausede og kom tilbage til videoen, sådan som vi havde designet for, og når de fandt det nødvendig derudover. (Kurven stiger, når mange studerende afspiller videoen og falder, når den pauses. Cursor'en er her sat der, hvor der i videoen for anden gang opfordres til pause og besvarelse af spørgsmål i et andet digital rum (Socrative.com)).

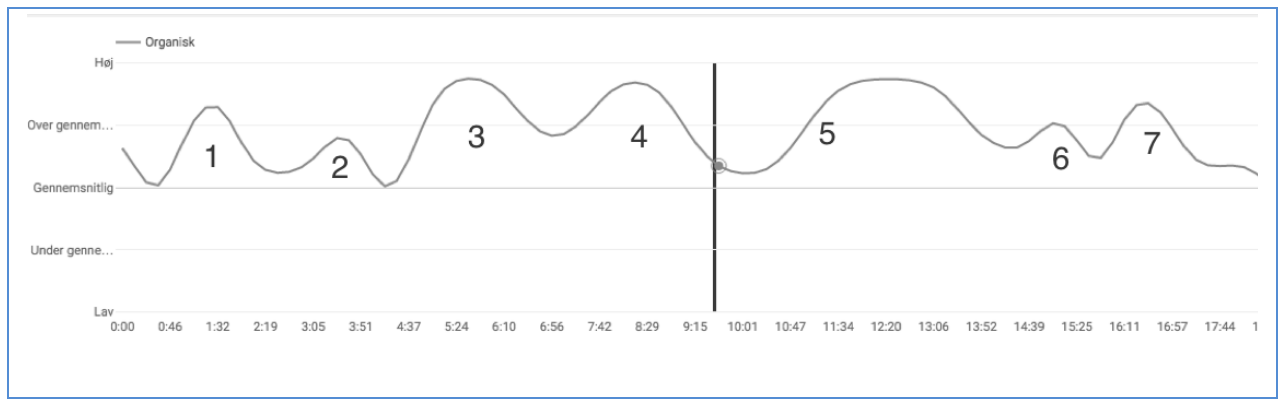

Figur 3: Kurve over viewing patterns i videoen med aktiviteter.

Imidlertid viste også den anden video en kurve med fald og stigninger omend mindre frekvente sammenlignet på den første. Dette indikerede, at de studerende, også mens de så denne video uden nærmere stilladsering, holdt pauser og kom tilbage til videoen efterfølgende.

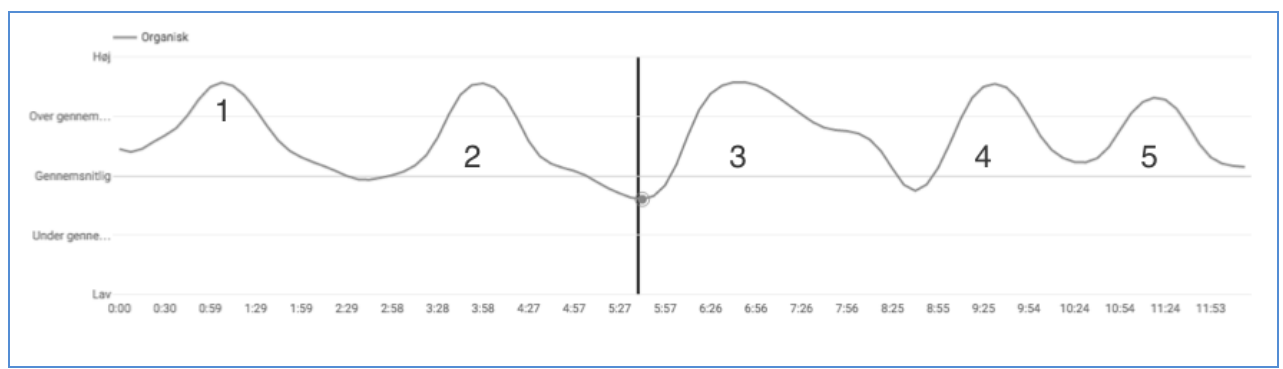

Figur 4: kurve over viewing patterns i videoen uden aktiviteter.

Begge kurver viste altså, at de studerende så videoerne til ende, og at de forholdt sig aktivt til dem, mens de så dem, enten fordi de blev bedt om det, eller fordi de selv fandt det nødvendigt, fx for at tage noter eller hente en kop kaffe, ved at spole over kendt stof, for at søge efter en bestemt formulering eller reference.

Mens de studerende svarede på quizzer med faktuelle spørgsmål og med umiddelbar feedback til dem, genereredes naturligvis også data. Disse bestod her i de studerendes svar og spørgsmål til besvarelse på seminaret. Af skemaet nedenfor (figur 6) fremgår det, at de fleste af de studerende fik let styr på udvalgte temaer i videoen (\#1,\#2 og \#3), og at mange af de studerende (\#7) havde længere spørgsmål, de ønskede videre behandlet på seminaret, og som de så videoen og quizspørgsmålene give anledning til. Især 
ses det, at et vanskeligt og flertydigt spørgsmål (\#6) bidrog til eftertanke, og at flertallet af besvarelserne var "forkerte" her.

\begin{tabular}{|c|c|c|c|c|c|c|c|c|}
\hline Name $A-Z=$ & Progress 0 & $\# 1$ & \#2 & \#3 & $\# 4$ & $\# 5$ & \#6 & \#7 \\
\hline$\star \star \star \star \star \star *$ & $100 \%$ & A & True & False & You tube & c & A & Hvorfor \\
\hline 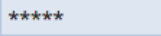 & $100 \%$ & c & True & False & Jeg mene & D & A & Nej \\
\hline$\star \star * \star * *$ & $100 \%$ & c & True & False & Filmstri & D & c & Hvad giv \\
\hline$\star \star * * * *$ & $86 \%$ & c & True & False & Jeg vil & C & c & \\
\hline$\star \star \star * \star *$ & $100 \%$ & c & True & False & Jeg har & D & c & Jeg husk \\
\hline 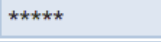 & $100 \%$ & $\mathrm{c}$ & True & False & 1. Hvis & c & $\mathrm{C}$ & Jeg klik \\
\hline 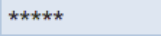 & $100 \%$ & c & True & False & Audacity & c & D & . \\
\hline ***** & $29 \%$ & B & True & & & & & \\
\hline$\star \star \star \star \star \star *$ & $100 \%$ & c & True & False & Garage B & c & c & Jeg vil \\
\hline$\star * \star * * *$ & $100 \%$ & c & True & False & Tiki-tok & D & c & . \\
\hline$\star \star \star \star \star \star *$ & $100 \%$ & $\mathrm{c}$ & True & False & "Didakti & c & $\mathrm{A}$ & Nej \\
\hline 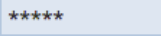 & $43 \%$ & c & True & False & & & & \\
\hline$\star * * * * *$ & $86 \%$ & c & True & False & Langt de & c & c & \\
\hline$\star \star \star \star \star \star *$ & $43 \%$ & c & True & False & & & & \\
\hline$\star \star \star * * *$ & $100 \%$ & c & True & False & filsmtri & c & A & har skre \\
\hline$\star * * * * *$ & $100 \%$ & $\mathrm{c}$ & True & False & Filmstri & $\mathrm{c}$ & $\mathrm{A}$ & Hvad er \\
\hline$\star \star \star * \star *$ & $100 \%$ & c & True & False & Jeg vil & c & c & De komme \\
\hline 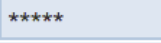 & $100 \%$ & $\mathrm{c}$ & True & False & Jeg mene & C & $\mathrm{c}$ & $?$ \\
\hline$\star \star \star \star * \star *$ & $100 \%$ & c & True & False & Batterik & c & D & $\varnothing v$ - var \\
\hline$\star \star \star * * *$ & $100 \%$ & c & True & False & $\mathrm{Hei}$, jeg & c & B & . \\
\hline Class Total & & $90 \%$ & $100 \%$ & $100 \%$ & & $76 \%$ & $29 \%$ & \\
\hline
\end{tabular}

Figur 5: Visualisering af besvarelser og spørgsmål fra Socrative.com

Disse learning analytics resultater skabte derfor behov for at spørge de studerende nærmere om deres viewing patterns eller video podcast adfærd og begrundelser herfor. Disse stillede vi på F2F seminaret som et element i undervisningen og i forlængelse af opsamlingen på de studerendes spørgsmål. De studerende diskuterede her fordelene i at kunne se, pause, spole, gentage osv., og mange af de studerende fortalte, at de normalt spolede i videoerne både for at holde sig koncentrerede og for at gøre det mere effektivt at lytte til en forelæsning. Nedenstående citat samler denne tilgang:

"Jeg spolede altså i dem. Jeg kunne se, hvor lange de var, og så var det mere effektivt at høre det lidt hurtigt"

Andre fortalte modsat at det, der åbenbart blev oplevet som en langsom og lidt snakkende form i forelæsningen, var en behagelig og udbytterig måde at gennemgå tekst og teori på. Dette udtryktes bl.a. som:

"Det var hyggeligt og jeg kunne godt lide, at man kunne se, hvordan du bor. Rigtig dejlig måde at få noget gennemgået på" 
Opsamlende på brugen af learning analytics i dette element i et didaktisk design kan der derfor peges på, at designet ikke bevirkede tydelige forskelle mellem de studerendes interaktioner med de to videoer. Derimod så vi, at links til yderligere aktiviteter på andre platforme (i Socrative) gjorde det lettere at arbejde videre med spørgsmålene og indholdet af videoen på seminaret og således skabe forbindelse mellem læringsomgivelserne online og F2F. Endvidere sås det, at data fra YouTube, fra quiz i Socrative og fra samtale F2F med de studerende i undervisningen tilsammen indikerede, at nok kan der gennem didaktisk design opfordres til, at de studerende bevæger sig mellem forskellige digitale spaces og udfører forskellige aktiviteter, men de viser også, at de studerende aktivt forholder sig til og reagerer (jf. Beetham) på dette design (Wenger, 1998) meget aktivt. Dette gav endvidere anledning til refleksioner over, at det ikke alene kan ses som en fordel at designe for mange læringsveje inden for det enkelte didaktiske design; det kan også være hensigtsmæssigt fx at gøre brug af læringsressourcer, som lægger op til forskelligartede reaktioner, og som kan tilpasse sig den enkelte studerende. Dette er jo let nok at sige, men vanskeligere at gøre konsekvent, så hvordan vi fremover udfolder det, skal vi fortsat arbejde med på modulet i samarbejde med de studerende.

\section{Case II: Studerendes reaktioner på øjenkontakt i video podcasts}

Ovenfor så vi, hvordan learning analytics i en konkret case bidrog til evaluering af elementer i et læringsdesign, og at analyserne af data skabte udgangspunkt for refleksion over videre bearbejdelse af dette design fremover. Nedenfor vil jeg vise, hvordan learning analytics kan bidrage til "[...] understanding and optimizing learning and the environments in which it occurs" (Vatrapu et al., 2011). I den nedenstående case skabte learning analytics nemlig med viden om, hvordan et enkelt element $i$ en video podcast kan have betydning for læring hos de studerende, og det kan dermed pege på forbedringer i et konkret didaktisk design. Forskning peger nemlig på, at underviseres brug af it i sig selv har betydning for, hvordan de studerende evaluerer undervisningen generelt (Cárdenas Claros \& Oyanedel, 2016).

Denne case er ligesom den ovenfor beskrevne fundet i masteruddannelsen blandt et hold studerende, der var optaget af it-didaktisk design i dette modul. Derfor blev de både præsenteret for og skulle selv arbejde med, skabe, teste, re-designe, evaluere og reflektere over it-didaktisk design under inddragelse af mange forskellige teknologier og læringsressourcer. Med samme begrundelse som den ovenfor nævnte nemlig at skabe sammenhæng mellem de studerendes aktiviteter online og F2F og at udnytte F2F-tiden på seminaret bedre ved bl.a. at lægge forelæsninger ud på videopodcast, optog jeg yderligere to videoer med henblik på - og ved brug af learning analytics fra YouTube og refleksionsspørgsmål til de studerende - at undersøge deres reaktioner på øjenkontakt eller mangel på samme i video podcastet oplæg. 
Øjenkontakt er en vigtig social del (Moyer, 2016) af det kropssprog, man bl.a. benytter i F2F-undervisning. Både ældre og nyere undersøgelser peger på, at øjenkontakt fra underviseren tjener flere formål og har stor betydning for, hvor troværdig underviseren opfattes (Beebe, 1974). Hvis der således er øjenkontakt mellem underviser og studerende løbende, så styrkes både engagement og interaktioner mellem dem (Andersen, 1979; Korthagen, Attema Noordewier, \& Zwart, 2014). Der peges således på, at øjenkontakt kan betragtes som en støtte for læring (Lin \& Creswell, 1989) og som en hjælp for de studerende under kognitive øvelser (Dalzel-Job, Oberlander, \& Smith, 2011). Sådanne undersøgelser i F2F-kontekster kan endvidere ses konkludere, at det gensidige blik kan udgøre "a multimodal resource in organizing activities" bl.a. i turtagning under diskussion og meningsforhandling (Mondada, 2006; in Satar, 2013). Undersøgelser viser endvidere, at når underviseren kigger på de studerende, mens han eller hun holder forelæsning eller oplæg, så er det mere sandsynligt, at de studerende lytter bedre efter og bliver interesserede i at lære mere (Hains Wesson, 2011).

Når det kommer til online undervisning, forholder det sig imidlertid (som altid) lidt mere kompliceret. Hvis en forelæsning nemlig medieres via $\mathrm{fx}$ synkron videokonference eller asynkront på video podcast, så må øjenkontakten mellem underviser og studerende udfoldes på nye måder (Develotte, Guichon, \& Vincent, 2010), fordi kropssprog ikke kan vises eller tolkes på samme måde bag computerskærmen, som det kan, når man er på samme fysiske sted (Pytash \& O’Byrne, 2014). Hvis en underviser derfor online vil give sine studerende indtryk af, at han eller hun ser dem i øjnene, må vedkommende i stedet kigge ind i kameraet uden at møde nogens blik. Men hvis de studerende skal opleve sig inkluderet og tiltalt i undervisningen, tyder meget altså på, at opmærksomhed på øjenkontakt er vigtigt ikke mindst i virtuelle kontekster (Levinsen, Ørngreen, \& Buhl, 2013; Orman \& Whitaker, 2010).

Med disse undersøgelser som baggrund ville jeg derfor undersøge, hvordan mine studerende, der selv var optagede af it-didaktisk design, ville reagere på og reflektere over henholdsvis brugen og fraværet af øjenkontakt fra mig i en video podcast, der introducerede dem for den opgave, de skulle arbejde med i løbet af modulet. Jeg optog derfor oplægget med to kameraer: det ene fra en vinkel, hvor jeg kiggede ind i det og således "havde øjenkontakt" med de studerende, mens det andet kamera optog mit oplæg, hvor jeg blev set fra siden. 

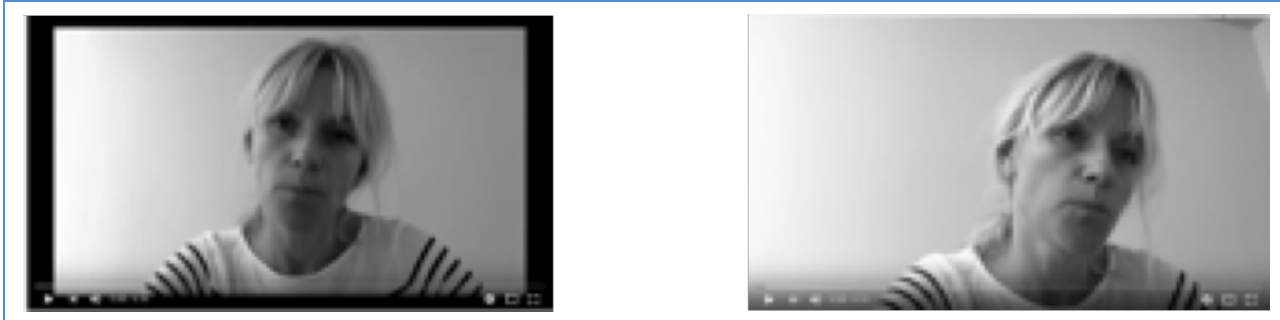

Figur 6: Screendumps fra videoerne hhv med og uden øjenkontakt

De studerende blev inddelt tilfældigt i to grupper, og hver gruppe fik tilsendt et link til den ene af optagelserne. Den ene gruppe studerende fik oplevelsen af, at jeg ikke på noget tidspunkt kiggede på dem, og jeg var altså interesseret $\mathrm{i}$ at se, hvorvidt dette forhold havde nogen betydning for deres oplevelse af læringsudbytte.

\section{Data}

Jeg undersøgte øjenkontakten gennem to datakilder: Den ene blev skabt gennem en survey til de studerende, som de besvarede umiddelbart efter, de havde set videoen. Spørgsmålene fokuserede på de studerendes egne vurderinger af, hvor godt de havde forstået indholdet i videoen, om de mente, de havde styr på opbygningen af opgaven, og om de generelt vurderede at øjenkontakt er vigtigt i en video podcast. Til sidst blev de studerende bedt om at overveje og nedskrive, hvordan de selv ville designe en lignende video podcast. Den anden datakilde stammede, ligesom vi så det ovenfor, fra YouTube's statistik over "relative audience retention". Med visualiseringen af disse data ville jeg se, om kurverne viste samme mønstre, som det sås i videoen med/uden aktiviteter, og som handlede om fagligt og teoretisk indhold sammenlignet med denne video, der orienterede om opbygningen af opgaven og dermed formodedes at være lettere tilgængelig.

Det viste sig imidlertid, at der var meget stor forskel på de to kurver indbyrdes og også i sammenligning med de i case I fremstillede. Kurven for videoen med øjenkontakt, hvor der ikke sås andet på billedet end mit talende ansigt, ses af figur 7. 


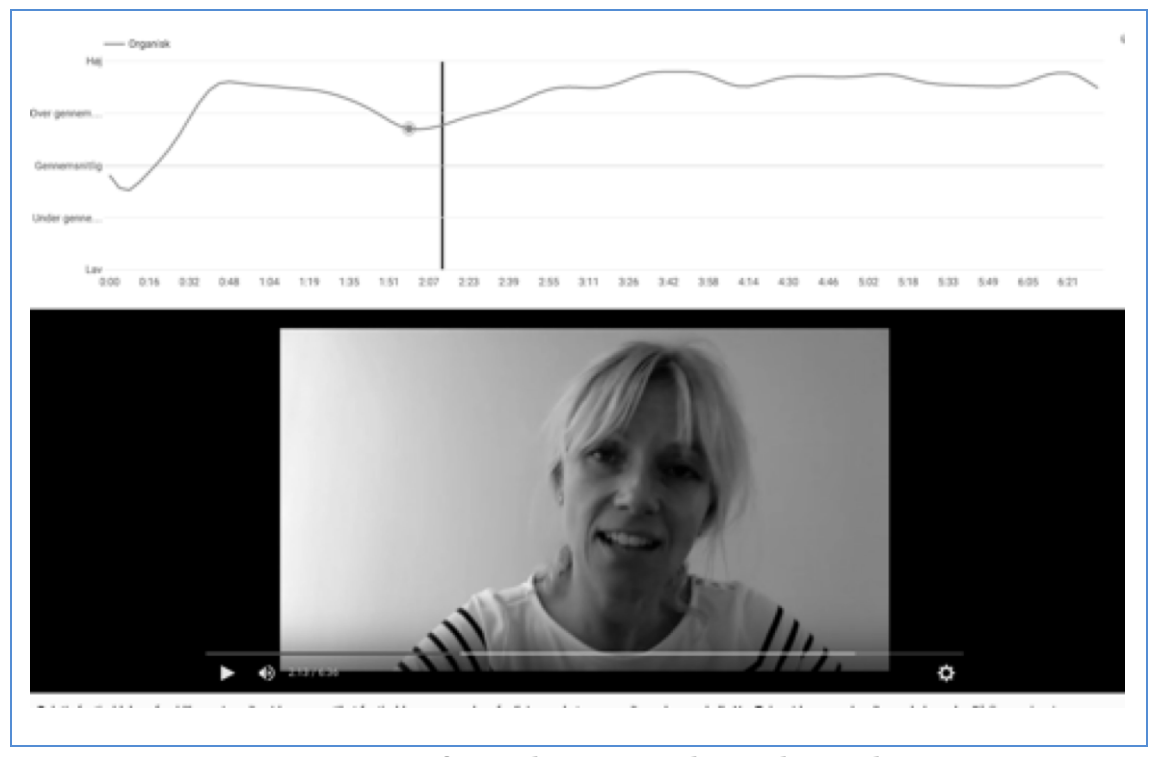

Figur 7: Viewing pattern fra videoen med øjenkontakt

Kurven viser altså, at de 12 studerende i denne gruppe overordnet så videoen igennem uden større afbrydelser, gentagelser eller andre interaktioner med den. Faldet i starten kan være udtryk for, at der er en del, der har fundet videoen på YouTube men udskudt at se den til et senere tidspunkt. Det fremgår, at de studerende så videoen til ende.

Meget anderledes ser kurven for videoen uden øjenkontakt ud. Her ses store udsving, hvilket tyder på, at denne gruppe studerende har sat på pause, spolet eller stoppet filmen.

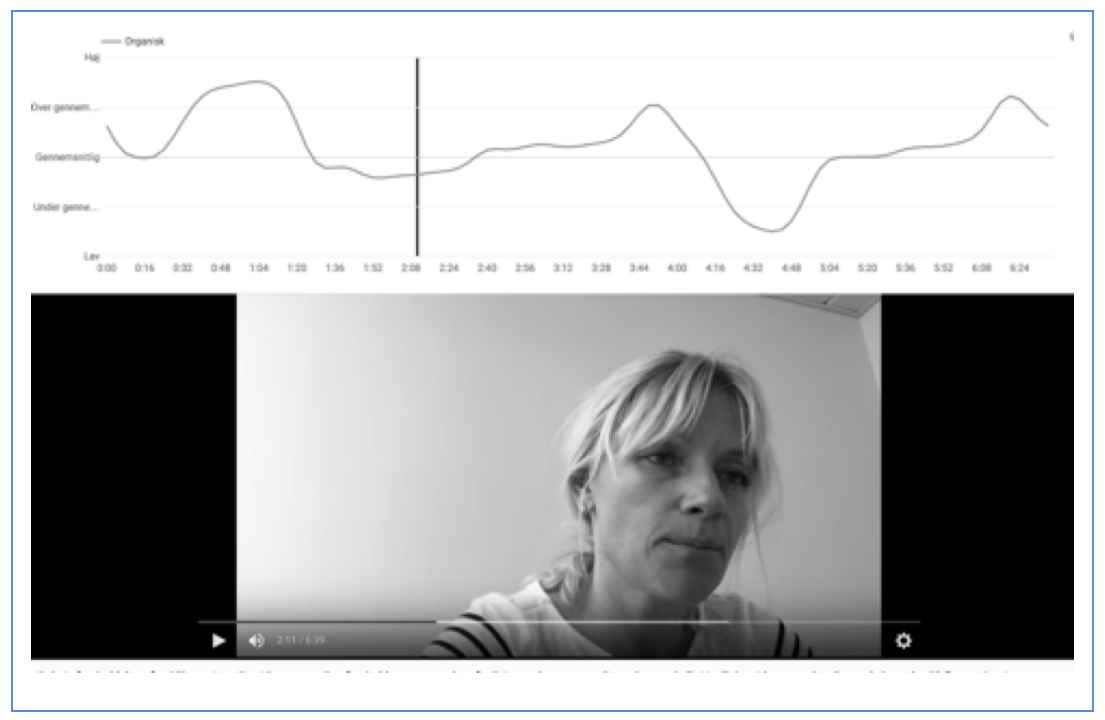

Figur 8: Viewing pattern for videoen uden øjenkontakt

Med disse første data tyder det altså på, at de studerende bedre fastholdes videoen igennem når de oplever øjenkontakt. Mange spørgsmål melder sig dog også, for kurven fortæller jo ikke, hvorfor disse viewing patterns er forskellige: har de studerende overhovedet set videoen med øjenkontakt, eller 
har den bare spillet ud i det blå, giver den manglende øjenkontakt i højere grad anledning til at de studerende arbejder aktivt (sætter på pause og tager noget, diskuterer med hinanden, henter kaffe og kommer friske tilbage), mens øjenkontakten fx dysser dem i søvn eller paralyserer dem?

For således at kunne svare på spørgsmålet om, hvilken (om nogen overhovedet) læringsmæssig reaktion, øjenkontakten eller fraværet af den vurderedes at have hos denne gruppe studerende, skal vi se på resultaterne af deres survey-svar og ideer til forbedringer af video podcast som læringsressource.

Hovedformålet med denne video var at introducere de studerende for en fornuftig opbygning af opgaven, hvilket er et tema, de studerende ofte spørger til, viser erfaring fra de tidligere moduler. Inden de studerende så videoen, var de ikke oplyst om den yderligere øjenkontakt-tematik. Først i survey'ens spørgsmål blev de klar over dette designrelaterede tema.

Overraskende nok viste det sig, at den gruppe, der oplevede øjenkontakt, vurderede en sådan mindre vigtig sammenlignet med den anden gruppes svar (se tabel 1).

\begin{tabular}{|l|l|l|l|l|l|}
\hline & $\begin{array}{l}\text { Meget } \\
\text { vigtigt }\end{array}$ & Vigtigt & $\begin{array}{l}\text { Ikke særlig } \\
\text { vigtigt }\end{array}$ & $\begin{array}{l}\text { Kun stemmen er } \\
\text { vigtig }\end{array}$ & alt \\
\hline Uden & 2 & 6 & 1 & 0 & 9 \\
\hline Med & 0 & 5 & 1 & 1 & 7 \\
\hline I alt & 2 & 11 & 2 & 1 & 16 \\
\hline
\end{tabular}

Tabel 1: De to gruppers svar (Uden øjenkontakt og Med øjenkontakts) på spørgsmålet "Hvor vigtigt er øjenkontakt i video podcasts?"

Nu er det jo en meget lille sample, og megen usikkerhed kan derfor påregnes, men et forsøg på en forklaring på det overraskende svar kunne måske findes $\mathrm{i}$ framingen (Goffman, 1974) af videoen som oplæg: Når der her er øjenkontakt, sker formidlingen som forventet, og intet påberåber sig derfor nærmere opmærksomhed. Når imidlertid øjenkontakten mangler, og optagelsen virker forstyrrende, fordi underviseren kun ses fra siden, og det virker, som om det er andre, der tales til, ja så maner det til eftertanke, og øjenkontakten - eller rettere manglen på den - kommer i fokus.

Det tydeligste resultat viser sig i spørgsmålet om generelt at vurdere videoen. Her ses det, at næsten alle i gruppen, der fik øjenkontakt, vurderede, at det var let at følge indholdet, hvilket stemmer med resultatet fra YouTube's viewing pattern fra denne gruppe. Gruppen, der så det talende hoved fra siden, placerede sig i højere grad i den utilfredse del og vurderede at filmen enten var for lang eller for vanskelig (en enkelt lagde sig i den tvetydige 
mellemposition og vurderede filmen som hverken for lang eller for kort, og 3 ud af de 9 mente, det var let at følge med).

\begin{tabular}{|l|l|l|l|l|l|}
\hline & $\begin{array}{l}\text { Let at } \\
\text { følge }\end{array}$ & $\begin{array}{l}\text { For } \\
\text { lang }\end{array}$ & $\begin{array}{l}\text { Hverken for lang } \\
\text { eller kort }\end{array}$ & $\begin{array}{l}\text { For } \\
\text { vanskelig }\end{array}$ & I alt \\
\hline Uden & 3 & 2 & 1 & 3 & 9 \\
\hline Med & 6 & 0 & 0 & 1 & 7 \\
\hline I alt & 9 & 2 & 1 & 4 & 16 \\
\hline
\end{tabular}

Tabel 2: De to gruppers svar (Uden øjenkontakt og Med øjenkontakts) på spørgsmålet "Hvad mener du om video podcasten?"

På spørgsmål til, om de to grupper efter videoen nu mente, de havde styr på opgavens opbygning, var der imidlertid ingen forskel på svarene. Alle studerende fik altså fat i indholdet; men der var stor forskel på, hvordan videoen oplevedes, og hvor godt de vurderede videoen blev udnyttet som læringsressource. Dette stemmer med andre undersøgelser (Beebe, 1974; Lin \& Creswell, 1989; Satar, 2013), der også finder, at øjenkontakt i video er nødvendig for at stilladsere studerendes opmærksomhed og styrke deres tilfredshed med dem.

\section{Design som framing af designrefleksioner}

De studerende blev som nævnt endvidere bedt om at udfolde, hvordan de selv vil designe en tilsvarende video podcast, og her grupperede svarene sig i to grupper afhængigt af, om den studerende havde set videoen med eller uden øjenkontakt. Svarede analyserede jeg i forhold til hvilken teknologi, de ville inddrage i videoen (skrift, billede, tegninger, figurer, modeller, kropssprog, apps, programmer fx), i forhold til hvad de pegede på som evt. mangler ( $\mathrm{fx}$ øjenkontakt, bevægelse, tekst). Det viste sig imidlertid, at de to gruppes besvarelser samlede sig om særlig sprogbrug: De studerende, der havde haft øjenkontakt, efterspurgte mere tekst, mens gruppen uden snarere foreslog tydeligere brug af designelementer, der gjorde brug af synet, det at se og kigge. Nedenfor har jeg samlet alle svarene og understreget denne pointe med gruppering i forhold til ord relateret til tekst hhv. syn. Kommentarerne neden for stammer fra øjenkontaktgruppen, og de svarer på spørgsmålet: "Hvis video skulle forbedre, hvilke elementer skulle da ændres?"

"Evt. stikord på skærmen eller en "indholdsfortegnelse" i starten, så man ved, hvad der kommer."

"Brug understøttende tekst, fx bullets til de fire dele af opgaven."

"En skriftlig gennemgang, punktopstilling evt., i starten af videoen." 
"Hvis man havde mere tid, kunne det være lækkert med tekst til at underbygge det talte.

"evt. visuelle tegn, der kan underbygge informationerne. Det kunne fx være en oversigt over indholdsdelene"

Selvom ikke alle svarene fra gruppen nedenfor fokuserer på den manglende øjenkontakt i den video, de så, så bruger de ord, der har med syn at gøre:

"Du skal kigge direkte i skærmen. Det virker som om at du snakker til en evt. sidemand til mig."

"At se mere direkte ind i kamaraet"

"Indexmarkeringer - kan man det på youtube?"

"En fin oplysende video. Forbedringer kunne dog være, at se ind kameraet"

"Man kunne veksle mellem at se dig og optage skærmen, hvor der vise det du taler om, ved at optage skærmen, mens du taler. Du kunne også se ind $i$ webkameraet, så man følger at du taler til en og ikke en der sidder ved siden af."

"Pointerne kunne være vist med tekst, men så går formålet med dette spørgeskema lidt i stykker."

"Dejligt hvis afsenderen kigger ind i sit webcam. Var det et gimmick?"

To studerende fra hver gruppe havde dog ingen ændringsforslag men fandt videoen med eller uden øjenkontakt helt fin. De skriver:

"Ingenting skal ændres"

"Videoen som instruktion opfylder sit mål til fulde"

"Det skal den ikke, den var rigtig fin, og meget informativ"

"Det er super"

Igen skal det påpeges, at gruppen, der besvarede spørgsmålene var meget lille, og nogle af de studerende fra gruppen med manglende øjenkontakt endvidere fik mistanke om, at de måske deltog i et forsøg, og derfor ikke tog spørgsmålet helt alvorligt; så der skal tages alle mulige forbehold for hurtige konklusioner på denne undersøgelse. Alligevel turde det være tydeligt, at øjenkontakten eller manglen på samme samt fraværet af andre elementer til støtte af det talte ord, på forskellig vis inspirerede de studerende tænkning i relation til design af en læringsressource som en video. Således tyder det på, at hvis forventede elementer som i dette tilfælde øjenkontakt er fraværende, kan det tiltrække sig næsten al opmærksomheden og hæmme videre tanker her i relation til multimodal støtte $\mathrm{fx}$ af talen. Således ses det, at også fraværende designelementer kan tiltrække sig megen didaktisk opmærksomhed. 


\section{Konklusion}

I denne artikel har jeg forsøgt at besvare et spørgsmål om, hvordan learning analytics gennem et mix af kvantitative og kvalitative data kan bidrage til at udvide en forståelse af studerendes læring og interaktioner med læringsressourcer. I den ene case blev learning analytics brugt til undersøgelse af, hvordan studerende på et konkret modul på universitetet interagerede med en læringsressource, når der bl.a. stilladseredes for bevægelser og aktiviteter mellem flere virtuelle platforme og F2F-møde efterfølgende. Her bidrog data fra Youtube og de studerendes besvarelser af quizz med at skabe et mere nuanceret billede af en gruppe studerende og deres interaktioner med en læringsressource og ikke mindst med begrundelser herfor. Dette gav anledning til refleksioner over, hvilke indholdsområder der med fordel kunne formidles på videopodcasts fremover, og hvordan der kan designes, så de studerende får så mange veje som muligt at følge til målet, selvom kontekstuelle forhold kan forstyrre designet på mangfoldige måder. Ved inddragelse af digitale data kan der således generelt skabes større nuancering i de svar, man kan få på spørgsmål af evaluerende og undersøgende didaktisk karakter. Fastholdes nemlig forståelsen af undervisning som et felt, der er mere komplekst end raketvidenskab (jf. Laurillard, 2012), så må det nok følge, at det er meget vanskeligt at undersøge præcist og indiskutabelt, om et konkret didaktisk design eller element heri virker eller ej helt generelt, og derfor er nuancering af forståelsen af didaktisk design af stor vigtighed.

I den anden case bidrog learning analytics til en undersøgelse af betydningen af et enkelt parameter i et didaktisk design, nemlig øjenkontakt i videopodcasts. Her viste data både i form af de "traces" (jf. Duval\& Verbert, 2012), de studerende satte på YouTube, og af deres skriftlige og mundtlige svar på spørgsmål, at bevidst brug af øjenkontakt kan fastholde de studerende og skabe en mere behagelig oplevelse af videoen, mens imidlertid en større grad af brug af multimodal understøttelse af talen sås at kunne opmuntre til mere selvstændig aktivitet blandt de studerende.

Netop i kontekster, hvor de studerende arbejder uden for det rum, der fysisk deles med underviseren, kan det være en stor fordel at gøre brug af den store mængde digitale data, der genereres af de studerende, hvis man ønsker at skabe sig et indblik i eller overblik over, hvordan de studerende reagerer på det didaktiske design. Imidlertid ses det også, at en sådan brug af learning analytics nok kan bidrage til nuancering af svar på undersøgende didaktiske spørgsmål, men at der samtidig hermed rejses spørgsmål til videre undersøgelser og eksperimenter med didaktisk design. Learning analytics kan således i lige så høj grad med at rejse nye spørgsmål som med at levere svar. 


\section{Referencer}

Alexandros, K., Alexandros, K., \& Georgios, E. (2013). A framework for recording, monitoring and analyzing learner behavior while watching and interacting with online educational videos. 2013 IEEE 13th International Conference on Advanced Learning Technologies, 7, 20-22.

Andersen, J. F. (1979). Teacher immediacy as a predictor of teacher effectiveness. In D. Nimmo (Ed.), Communication yearbook 3 (pp. 543559). New Brunswick, NJ: Transaction Books.

Anderson, T. (2004). Toward a theory of online learning. In T. Anderson, \& F. Elloumi (Eds.), The theory and practice of online learning. Athabasca University Press.

Beebe, S. A. (1974). Eye contact: A nonverbal determinant of speaker credibility. The Speech Teacher, 1(23), 21-25.

Beetham, H. (2013). Designing for active learning in technology-rich contexts. Rethinking pedagogy for a digital age: Designing for 21st century learning (pp. 31-48) Routledge.

Cárdenas Claros, M., \& Oyanedel, M. (2016). Teachers' implicit theories and use of ICTs in the language classroom. Technology, Pedagogy and Education, 25(2), 207-207-225.

Clow, D. (2013). An overview of learning analytics. Teaching in Higher Education, 18(6), 683-695.

Dalzel-Job, O., Oberlander, J., \& Smith, T. J. (2011). Don't look now: The relationship between mutual gaze, task performance and staring in second life. Proceedings of the 33rd Annual Conference of the Cognitive Science Society, 832-837.

De Boer, J., Kommers, P. A., \& De Brock, B. (2011). Using learning styles and viewing styles in streaming video. Computers \& Education, 56(3), 727735.

Develotte, C., Guichon, N., \& Vincent, C. (2010). The use of the webcam for teaching a foreign language in a desktop videoconferencing environment. ReCALL, 22(03), 293-312.

Dupagne, M., Millette, D. M., \& Grinfeder, K. (2009). Effectiveness of video podcast use as a revision tool. Journalism \& Mass Communication Educator, 64(1), 54-70.

Duval, E., \& Verbert, K. (2012). Learning analytics. E-Learning and Education, 8(1), 1-5.

Dyckhoff, A. L., Zielke, D., Bültmann, M., Chatti, M. A., \& Schroeder, U. (2012). Design and implementation of a learning analytics toolkit for teachers. Educational Technology \& Society, 15(3), 58-76.

Gaševic, D., Dawson, S., Rogers, T., \& Gasevic, D. (2016). Learning analytics should not promote one size fits all: The effects of instructional 
conditions in predicting academic success. The Internet and Higher Education, 28, 68-84.

Goffman, E. (1974). Frame analysis: An essay on the organization of experience. Harvard University Press.

Green, S. M., Voegeli, D., Harrison, M., Phillips, J., Knowles, J., Weaver, M., \& Shephard, K. (2003). Evaluating the use of streaming video to support student learning in a first-year life sciences course for student nurses. Nurse Education Today, 23(4), 255-261.

Hains Wesson, R. (2011). The impact of performance skills on students' attitudes towards the learning experience in higher education. Issues in Educational Research, 21(1), 22-22-.

Heilesen, S. B. (2010). What is the academic efficacy of podcasting? Computers \& Education, 55(3), 1063-1068.

Hill, J. L., \& Nelson, A. (2011). New technology, new pedagogy? employing video podcasts in learning and teaching about exotic ecosystems. Environmental Education Research, 17(3), 393-408.

Jarvis, C., \& Dickie, J. (2009). Acknowledging the 'forgotten'and the 'unknown': The role of video podcasts for supporting field-based learning. Planet, (22), 61-63.

Johnson, L., Smith, R., Willis, H., Levine, A., \& Haywood, K. (2011). The 2010 horizon report. (No. The New Media Consortium, 2010). Austin, Texas:

Kay, R. H. (2012). Exploring the use of video podcasts in education: A comprehensive review of the literature. Computers in Human Behavior, 28(3), 820-831.

Korthagen, F. A. J., Attema Noordewier, S., \& Zwart, R. C. (2014). Teacherstudent contact: Exploring a basic but complicated concept. Teaching and Teacher Education, 40, 22-32.

Laurillard, D. (2012). Teaching as a design science. building pedagogical patterns for learning and technology. New York: Routledge.

Levinsen, K., Ørngreen, R., \& Buhl, M. (2013). Telepresence as educational practice in the third Teaching-Room-a study in advanced music education. Proceedings of the 12th European Conference of E-Learning. Sonning Common: Academic Conferences and Publishing International Limited, 250-257.

Lin, C. A., \& Creswell, K. W. (1989). Effects of televised lecture presentation styles on student learning. Learning, Media and Technology, 15(1), 3752 .

Merceron, A., Blikstein, P., \& Siemens, G. (2016). Learning analytics: From big data to meaningful data. Journal of Learning Analytics, 2(3), 4-8. 
Mondada, L. (2006). Participants' online analysis and multimodal practices: Projecting the end of the turn and the closing of the sequence. Discourse Studies, 8(1), 117-129.

Moyer, M. W. (2016). Eye contact: How long is too long? Scientific American Mind, 27(1), 8-8.

Nortvig, A., \& Sørensen, B. H. (2016). Video podcasts: Learning by listening? Proceedings for the 5th International Conference of Designs for Learning. Aalborg University Copenhagen, Denmark.

Orman, E. K., \& Whitaker, J. A. (2010). Time usage during face-to-face and synchronous distance music lessons. The American Journal of Distance Education, 24(2), 92-103.

Persico, D., \& Pozzi, F. (2015). Informing learning design with learning analytics to improve teacher inquiry. British Journal of Educational Technology, 46(2), 230-248.

Pytash, K. E., \& O'Byrne, W. I. (2014). Research on literacy instructions and learning in virtual, blended, and hybrid environments. In R. E. Ferdig, \& K. Kennedy (Eds.), Handbook of research on K-12 online and blended learning (pp. 179-200) ETC Press.

Reyes, J. A. (2015). The skinny on big data in education: Learning analytics simplified. TechTrends, 59(2), 75-81.

Satar, H. M. (2013). Multimodal language learner interactions via desktop videoconferencing within a framework of social presence: Gaze. ReCALL: The Journal of EUROCALL, 25(1), 122.

Schwendimann, B. A., Rodriguez Triana, M. J., Prieto Santos, L. P., Shirvani Boroujeni, M., Holzer, A. C., Gillet, D., \& Dillenbourg, P. (2016). Understanding learning at a glance: An overview of learning dashboard studies. International Learning Analytics and Knowledge, (EPFL-CONF216917)

Siemens, G. (2012). Learning analytics: Envisioning a research discipline and a domain of practice. Proceedings of the 2nd International Conference on Learning Analytics and Knowledge, ACM. SoLAR. 4-8.

Tang, J. K., Xie, H., \& Wong, T. (2015). A big data framework for early identification of dropout students in MOOC. Technology in education. technology-mediated proactive learning (pp. 127-132) Springer.

Traphagan, T., Kucsera, J. V., \& Kishi, K. (2010). Impact of class lecture webcasting on attendance and learning. Educational Technology Research and Development, 58(1), 19-37.

Vajoczki, S., Watt, S., Marquis, N., \& Holshausen, K. (2010). Podcasts: Are they an effective tool to enhance student learning? A case study. Journal of Educational Multimedia and Hypermedia, 19(3), 349-362.

Vatrapu, R., Teplovs, C., Fujita, N., Bull, S., \& Long, P. (2011). Towards visual analytics for teachers' dynamic diagnostic pedagogical decision-making. 
Proceedings of the 1st International Conference on Learning Analytics and Knowledge - LAK'11, , 93-98.

Wenger, E. (1998). Communities of practice: Learning, meaning, and identity. New York: Cambridge university press.

Yasmin, D. (2013). Application of the classification tree model in predicting learner dropout behaviour in open and distance learning. Distance Education, 34(2), 218-231.

Zhang, D., Zhou, L., Briggs, R. O., \& Nunamaker, J. F. (2006). Instructional video in e-learning: Assessing the impact of interactive video on learning effectiveness. Information \& Management, 43(1), 15-27. 